\title{
Researcher creations? The positioning of policy texts in higher education research
}

\section{Paul Ashwin and Karen Smith}

\begin{abstract}
In this article we explore the way in which policy texts are positioned in a selection of higher education journal articles. Previous research has suggested that policy implementation studies have taken an uncritical approach to researching policies. Based on an analysis of articles published in higher education and policy journals in 2011, we argue that whilst these criticisms do appear to be valid, there is a bigger problem with the ways that policy texts are analysed and used in higher education research. This is that rather than subjecting particular policy texts to a sustained analysis, the majority of articles appear to focus on having an impact on policies that are very broadly conceived. We explore the implications of this and conclude by calling for more sustained, in-depth, analytical and critical research into the development and impact of higher education policies on higher education practices.
\end{abstract}

\section{Introduction}

A significant proportion of research into higher education is focused on examining higher education policies and their impact (Tight, 2012). Tight (2012) argues that policy research is a key focus of research into higher education because policies play a crucial role in shaping higher education practices. Similarly, educational policy research more generally has highlighted the ways in which policies shape research (Smith 2010). 
In press in Higher Education. Available at:

http://link.springer.com/article/10.1007/s10734-014-9819-9

The other side of this relationship is the extent to which educational research has an impact on policies (see for example the discussion between Hammersley 2005 and Chalmers 2005 as well as Saunders 2005), with educational researchers arguing that policy makers are often more interested in policy-informed evidence than evidence-informed policy (see for example, Hartley 2005). For their part, policy makers have criticised educational researchers for producing research that is not fit for informing policy. Drawing on reviews of educational research from the early to mid 1990s, Whitty (2006) outlines the ways in which policymakers see educational research as lacking rigor, noncumulative, theoretically incoherent and ideologically bias. Whitty (2006) argues that these disagreements between researchers and policy makers reflect the ways in which policy makers and researchers are engaged in very different kinds of activity with different concerns and in which evidence has different meanings.

In this article, we take another approach to thinking about the validity of these criticisms by analysing the ways in which policy texts are positioned in higher education research and the resulting ways in which policy research presents the character of higher education policies. In doing so, we argue that research 'creates' particular versions of policies that are equally as contestable as the policies themselves.

\section{The importance of policy texts}

Within policy research in higher education, as well as education more generally, there are two broad approaches to researching policy that appear to be in opposition to each other. Policy implementation studies examine the ways in which policies are implemented and the extent to which they meet their declared objectives (Hardy 2009). These kinds of studies are criticised by critical educational policy research on three counts. First, they are criticised for treating policy texts as the outcomes of rational discussions rather than outcomes of struggles which can be interpreted in 
In press in Higher Education. Available at:

http://link.springer.com/article/10.1007/s10734-014-9819-9

multiple ways (Ball 1994; Nudzor 2009). Second, the policy implementation approach is criticised for treating policies as responses to problems in the real world, whereas critical policy researchers seek to understand the ways in which policy texts seek to establish ways of seeing the world that lead to the recognition of particular kinds of problems and not others (Ball 1994; Bacchi 2000; Ozga 2000; Vidovich 2007; Weaver-Hightower, 2008; Saarinen 2008; Simons; Olssen, \& Peters 2009; Saarinen and Ursin 2012; Taylor Webb 2014). Finally, implementation studies are criticised for treating policies as if they are located at the level of the government, regional or institutional agency that has produced them rather than in terms of the relations between these policies and the many levels of practices that are enacted in response to them (Ball 1994; Lingard and Sellar 2013).

What is important for the present article is that whilst the meaning of policy texts is contested between these different approaches, they are still central to both. For implementation studies, they provide an account of the real world problem that the policy is attempting to solve, whilst for critical researchers it is the outcome of compromise and struggle, which can be understood in different ways. Thus whilst critical researchers are clear that policy is 'more than text' (Lingard and Sellar 2013), the texts are still crucial. For example, Ball (1994, p.18, emphasis in the original) emphasises that 'policies are textual interventions into practice' and policy texts remain central to models of policy research that take a more critical stance (for example, Taylor 1997; Vidovich, 2007). In this way the disagreements of these two approaches to policy research can be understood in terms of the meanings of policy texts but not in terms of their importance.

The reason that policy texts are important is because, whilst they can be interpreted in different ways, they are a durable and portable form of the practices that led to their development. Thus they are stable over time and open to reading and re-reading in a way that situated practices are not (Law 
In press in Higher Education. Available at:

http://link.springer.com/article/10.1007/s10734-014-9819-9

1994). Given their importance, it is interesting that there has been a lack of focus on analysing these texts in higher education research. For example, Saarinen (2008) argues that examples of discursive and textual approaches to policy analysis in higher education are rare. Tight (2012) highlights the lack of focus on the systematic analysis of documents in the policy analysis literature, whilst also arguing that most document analysis in higher education research does not give sufficient details about how the documents were analysed.

In this article, we examine the ways in which policy texts are used, analysed, and the outcomes that come from their use in higher education policy research. Based on our analysis of the relations between these factors, we argue that higher education policy research is in danger of appearing to create versions of policies that have little relation to actual policy texts. This problem is exacerbated by the tendency to claim that research has implications for policies without being precise about which policies are implicated by the outcomes of research.

\section{Methodological approach}

This article is part of a growing body of literature in higher education research which seeks to systematically analyse the ways in which different topics are dealt with in journal articles and books. In relation to higher education generally, this has included general reviews by Tight $(2007 ; 2012)$ and Ashwin's (2012) review of the way theories are developed in higher education research. Within policy studies generally, Hardy (2009) reviewed the analytical approaches and institutional locations of authors in the Journal of Educational Policy, Educational Evaluation and Policy Analysis in 2007-8. Finally, in relation to higher education policy, Saarinen (2008) analysed the use of text and discourse analysis in Studies in Higher Education, Higher Education and Journal of Higher Education Policy and Management, whilst Saarinen and Ursin (2012) analysed the approaches taken to understanding 
In press in Higher Education. Available at:

http://link.springer.com/article/10.1007/s10734-014-9819-9

changes in higher education policy change in the same three journals. As with the current research, all these reviews share the common weakness of only including articles and journals written in English.

In our analysis, we were interested in understanding the ways in which policy texts were used and analysed in articles examining higher education policies. In order to examine a broad range of articles that examined higher education policies, we examined three kinds of journals in our analysis. These were the six general higher education journals that were identified by Tight (2007) as the leading North American and non-North American higher education journals (Higher Education, Higher Education Research \& Development, Journal of Higher Education, Research in Higher Education, Review of Higher Education, Studies in Higher Education); four specialist higher education policy journals (Higher Education Management and Policy, Higher Education Quarterly, Higher Education Policy, Journal of Higher Education Policy and Management), and five general education policy journals (Educational Evaluation and Policy Analysis, Educational Policy, European Journal of Education, Journal of Education Policy, Policy Studies).

From each of these journals, we identified those articles, published in 2011, that explicitly focused on higher education policy by selecting articles that related to an aspect of higher education and used the term 'policy' in any of the title, abstract or keywords. In total 580 articles were published within the fifteen journals within the sample. Of these 580 articles, 99 higher education policy articles were identified and analysed. Table 1 sets out where the higher education policy articles we analysed were published. Unsurprisingly, the specialist higher education policy journals carried the highest proportion of higher education policy articles with $62 \%$ of articles in Higher Education Policy , 32\% of articles in Higher Education Quarterly and 30\% of articles in Journal of Higher Education Policy and 
In press in Higher Education. Available at:

http://link.springer.com/article/10.1007/s10734-014-9819-9

Management being focused on higher education policies. The proportion of higher education policy articles in general education policy journals was lower. This reflects their commitment to cover the whole education system. Of these, the Journal of Education Policy had the most higher education policy articles ( $20 \%$ of all articles in 2011). Within the general higher education journals, the Review of Higher Education had the most higher education policy articles (21\%). Within the sample of analysed articles, Higher Education (17\% of the total) had the highest number of higher education policy articles, followed by Higher Education Policy and Journal of Higher Education Policy and Management (both 16\%). This reflects the greater number of articles carried in Higher Education.

\begin{tabular}{|c|c|c|c|c|}
\hline & Journal title & $\begin{array}{c}\text { Total } \\
\text { number of } \\
\text { issues and } \\
\text { (articles) }\end{array}$ & $\begin{array}{l}\text { Percentage of } \\
\text { policy articles } \\
\text { within journal }\end{array}$ & $\begin{array}{l}\text { Percentage of } \\
\text { policy articles } \\
\text { within sample }\end{array}$ \\
\hline General & Higher Education & $12(90)$ & $19 \%(n=17)$ & $17 \%(n=17)$ \\
\hline $\begin{array}{l}\text { higher } \\
\text { education }\end{array}$ & $\begin{array}{l}\text { Higher Education Research \& } \\
\text { Development }\end{array}$ & $6(56)$ & $7 \%(n=4)$ & $4 \%(n=4)$ \\
\hline \multirow[t]{4}{*}{ journals } & Journal of Higher Education & $6(27)$ & $15 \%(n=4)$ & $4 \%(n=4)$ \\
\hline & Research in Higher Education & $8(40)$ & $15 \%(n=6)$ & $6 \%(n=6)$ \\
\hline & Review of Higher Education & 4 (19) & $21 \%(n=4)$ & $4 \%(n=4)$ \\
\hline & Studies in Higher Education & $8(56)$ & $11 \%(n=6)$ & $6 \%(n=6)$ \\
\hline \multirow{5}{*}{$\begin{array}{l}\text { Specialist } \\
\text { higher } \\
\text { education } \\
\text { policy } \\
\text { journals }\end{array}$} & Higher Education & $2(12)$ & $17 \%(n=2)$ & $2 \%(n=2)$ \\
\hline & Management and Policy & & & \\
\hline & Higher Education Quarterly & 4 (19) & $32 \%(n=6)$ & $6 \%(n=6)$ \\
\hline & Higher Education Policy & $4(26)$ & $62 \%(n=16)$ & $16 \%(n=16)$ \\
\hline & $\begin{array}{l}\text { Journal of Higher Education } \\
\text { Policy and Management }\end{array}$ & $6(53)$ & $30 \%(n=16)$ & $16 \%(n=16)$ \\
\hline \multirow{5}{*}{$\begin{array}{l}\text { General } \\
\text { education } \\
\text { policy } \\
\text { journals }\end{array}$} & $\begin{array}{l}\text { Educational Evaluation and } \\
\text { Policy Analysis }\end{array}$ & $4(24)$ & $8 \%(n=2)$ & $2 \%(n=2)$ \\
\hline & Educational Policy & $6(34)$ & $3 \%(n=1)$ & $1 \%(n=1)$ \\
\hline & $\begin{array}{l}\text { European Journal of } \\
\text { Education }\end{array}$ & $4(40)$ & $13 \%(n=5)$ & $5 \%(n=5)$ \\
\hline & Journal of Education Policy & $6(46)$ & $20 \%(n=9)$ & $9 \%(n=9)$ \\
\hline & Policy Studies & $6(38)$ & $3 \%(n=1)$ & $1 \%(n=1)$ \\
\hline \multirow[t]{2}{*}{ Totals } & 15 journals & 86 issues & $17 \%(n=99)$ & $100 \%(n=99)$ \\
\hline & & (580 articles) & & \\
\hline
\end{tabular}

Table 1: Types of journals, journal names, and percentages (numbers) of articles that were selected for analysis 
In press in Higher Education. Available at:

http://link.springer.com/article/10.1007/s10734-014-9819-9

\section{Approach to analysis}

In analysing the articles, we focused on the ways in which policy texts were positioned. We analysed the focus of the polices that were discussed in the article, the ways in which policy texts were used in the article, the ways in which they were analysed, and the outcomes of the article for policies. In order to ascertain inter-coder reliability across the fifteen journals, we initially analysed the articles in three of the journals (one from each category) independently and compared our analyses to ensure that we were selecting the same articles for analysis and analysing them in congruent ways. After each of these first three analyses, we discussed the ways in which we were conducting the analysis.

Once we were happy that we were selecting the same articles and analysing them in congruent ways, we then split the remaining journal articles between us. The findings from the review were analysed using descriptive statistics to show the frequencies of the different variables used in the study. Bivariate analysis was carried out using cross-tabulations to seek out relationships and patterns between these different variables.

\section{Caveats and potential misunderstandings}

There are three potential misunderstandings of what we are trying to achieve in this article, which we address before reporting our outcomes. First, it should be clear by now that our focus is on how policy texts are used in higher education journal articles. However, this does not mean that we are assuming that policies are implemented as they are set out in texts or that we do not see these texts as open to criticism. Rather our argument is that if we are going to undertake serious research into higher education policies then this needs to be based on what is actually contained in policy texts, even if the outcome of the research is to point out the differences between the rhetoric of policy texts and the quotidian policy enactments that these texts help to shape. 
In press in Higher Education. Available at:

http://link.springer.com/article/10.1007/s10734-014-9819-9

Second, our data only give us access to the ways in which policy texts are positioned within journal articles. When we examine, for example, the ways in which policy texts are analysed, this is based on what is reported in the articles from the journals we selected. We do not have access to other accounts of what happened in the research process and do not analyse articles from other journals. Therefore, our arguments need to be understood as relating to the way in which policy research is reported in a particular selection of journal articles rather than necessarily related to the ways in which the research was conducted.

Third in developing our criticisms, we are focusing on the collective practices involved in reporting higher education policy research rather than criticising individual articles or authors. All of the articles we examined were subject to peer review and therefore represent the outcomes of collective knowledge building practices in higher education policy research. It is for this reason that, in developing our arguments, we focus on exploring patterns in the sample of articles rather than discussing the detailed contents of individual articles.

\section{Findings}

\section{Focus}

In examining the focus of the articles, we looked at the subject area of the policies considered, the level the policies were situated at and the national location of the policies. The most common policy themes within the sample related to the higher education sector as a whole (15\%), equal opportunities (13\%), student experience (12\%) and learning, teaching and assessment (10\%), as can be seen in Table 2 . This table also shows that the articles were more likely to discuss policies emanating from North America (28\%) and Europe (20\%). The majority of the articles dealt with policies that operate at a national level (63\%). 
In press in Higher Education. Available at:

http://link.springer.com/article/10.1007/s10734-014-9819-9

\begin{tabular}{llll}
\hline Policy Focus & Percentage & Region of Policy & Percentage \\
\hline Higher Education Sector & $15 \%$ & North America & $28 \%$ \\
Equal Opportunities & $13 \%$ & Europe & $20 \%$ \\
Student Experience & $12 \%$ & Multi-National & $18 \%$ \\
Teaching, Learning and & $10 \%$ & Australia and Oceania & $14 \%$ \\
Assessment & & & \\
Research & $8 \%$ & Asia & $10 \%$ \\
Widening Participation & $7 \%$ & Middle East, North & $3 \%$ \\
& & Africa, Greater Arabia & \\
Financing HE & $6 \%$ & Sub-Saharan Africa & $3 \%$ \\
HE institutions & $6 \%$ & Not stated & $3 \%$ \\
\cline { 2 - 2 } Employability & $5 \%$ & Level of Policy & Percentage \\
\cline { 2 - 2 } Profession & $4 \%$ & National & $63 \%$ \\
Internationalisation & $4 \%$ & Institutional & $13 \%$ \\
Mobility & $4 \%$ & International & $13 \%$ \\
General Policy Focus & $3 \%$ & Regional/ State & $8 \%$ \\
Third Mission & $3 \%$ & Not Stated & $3 \%$ \\
\hline
\end{tabular}

Table 2: Focus, Region and Level of Policies in the Articles

We also examined the number of specific policies that each article examined. Most articles (54\%) discussed more than one named policy, whilst $20 \%$ focused on a single policy. Interestingly over a quarter $(26 \%)$ of the articles did not make any references to specific policies.

\section{How were the policies used in the articles?}

We identified five main ways in which policies were used in the articles. The most common way (38\%) was for the policies to be used to provide a general context for the substance of the article. This meant that they were used in the introduction to set the scene for the research but did not figure in the main analysis of the article. In $28 \%$ of the articles, the policies were used as a form of evidence. This could either be by using policies as evidence for the ways things are different over time or between contexts or as a reflection of the ways in which policies are constructed. In $22 \%$ of the articles, the policies were the object of analysis in the article. This could involve an evaluation of policies, different policies being compared, or policies being used to construct a model of policy development. In $8 \%$ of the articles, policies were not discussed. Finally, in 3\% of articles the policies 
In press in Higher Education. Available at:

http://link.springer.com/article/10.1007/s10734-014-9819-9

were an object of development in that the main focus of the article was to develop policies in some way.

\section{How were the texts of policies analysed?}

In the majority of articles in the sample (59\%), the texts of the policies were not analysed. In $18 \%$ of the articles, the policy texts were analysed but the approach taken to analysing them was not explained. In $14 \%$ of articles, the approach to analysis was described in very general terms, for example as a' textual analysis' but without any indication given of what this involved. Nine per cent of articles referred to a specific approach to analysing policy texts.

\section{What were the key outcomes?}

We identified four main types of outcomes that the articles had in relation to policies. In $41 \%$ of articles the outcome for policies was that the findings in the article had 'implications for policies'. This included making recommendations for policy changes based on the outcomes of the research or indicating that the findings would be of use to policymakers. In $25 \%$ of articles, the outcomes in relation to policies was the charting of the ways in which policies had developed. This included providing histories of particular policies, identifying trends across a number of policies, and identifying the reasons for particular policies being developed. In $20 \%$ of articles, there were no outcomes in relations to policies and in $13 \%$ the outcomes were a critique of policies, which included examining confusion over the use of terms in policies, mismatches between policies intentions and outcomes, and identifying the limits of particular policies. 
In press in Higher Education. Available at:

http://link.springer.com/article/10.1007/s10734-014-9819-9

\section{Relations between policy texts use, analysis and outcomes}

Table 3 shows the relationship between policy use and the analysis of policy texts. It shows that the analysis of policy texts was least likely where policies are used to provide a context; $71 \%$ of these articles do not analyse policies. A specified approach to the analysis of policy texts was most likely when policies are the object of analysis but only $23 \%$ of these articles take such an approach. A general textual analysis was most likely where policies were used as evidence ( $18 \%$ of these articles) and these articles were also most likely not to state their approach to policy analysis (32\%).

\begin{tabular}{lrrrrr}
\hline & & $\begin{array}{c}\text { General } \\
\text { Textual }\end{array}$ & $\begin{array}{c}\text { Specified } \\
\text { approach to }\end{array}$ & Total \\
& Not analysed & Not stated & Analysis & Analysis & \\
\hline Not discussed & $8(100 \%)$ & 0 & 0 & 0 & $8(100 \%)$ \\
Provides Context & $27(71 \%)$ & $8(21 \%)$ & $3(8 \%)$ & 0 & $38(100 \%)$ \\
Object of Analysis & $12(55 \%)$ & $1(5 \%)$ & $4(18 \%)$ & $5(23 \%)$ & $22(100 \%)$ \\
Policy as Evidence & $8(29 \%)$ & $9(32 \%)$ & $7(25 \%)$ & $4(14 \%)$ & $28(100 \%)$ \\
Object of Development & $3(100 \%)$ & 0 & 0 & 0 & $3(100 \%)$ \\
\hline Total & 58 & 18 & 14 & 9 & 99 \\
\hline
\end{tabular}

\section{Table 3: Relations between use and analysis of policy texts}

Table 4 shows the relations between the approaches taken to analysing policy texts and the outcomes in relation to policies. Where policies were not analysed the most frequent outcome was to provide implications for policies $(47 \%)$, followed by having no outcomes in relation to policies (33\%). In most (56\%) of the articles where the form of analysis was not stated, the outcome was to chart the development of policy texts. The next most common outcome (33\%) was to provide implications for policies. Where a general textual analysis was described, half the articles charted policy developments and $29 \%$ developed critiques of policies. Finally, two thirds of the articles that involved a named approach to policy analysis had implications for policies and a third charted policy developments. 
In press in Higher Education. Available at:

http://link.springer.com/article/10.1007/s10734-014-9819-9

\begin{tabular}{lrrrrr}
\hline & No outcome & $\begin{array}{c}\text { Implications } \\
\text { for policies }\end{array}$ & $\begin{array}{c}\text { Critiques of } \\
\text { policies }\end{array}$ & $\begin{array}{c}\text { Charts policy } \\
\text { development }\end{array}$ & Total \\
\hline Not analysed & $19(33 \%)$ & $27(47 \%)$ & $7(12 \%)$ & $5(9 \%)$ & $58(100 \%)$ \\
Not stated & 0 & $6(33 \%)$ & $2(11 \%)$ & $10(56 \%)$ & $18(100 \%)$ \\
General textual analysis & $1(7 \%)$ & $2(14 \%)$ & $4(29 \%)$ & $7(50 \%)$ & $14(100 \%)$ \\
Named approach to & 0 & $6(67 \%)$ & 0 & $3(33 \%)$ & $9(100 \%)$ \\
analysis & & & & & 25 \\
\hline Total & 20 & 41 & & 99 \\
\hline
\end{tabular}

Table 4: Relations between analysis of policy texts and the outcomes for policy in the articles

Finally we consider the relations between the ways in which policy texts were used, analysed and the outcomes in relation to policies, as set out in Table 5. Where there are no outcomes in relation to policies $(n=20), 95 \%$ of articles do not analyse policies and $65 \%$ the policies are simply used to provide a context for the article. With these articles it is not clear the extent to which they are actually articles that are focused on policy. Rather a general notion of 'policy' seems to be invoked in order to increase the sense that the articles have contemporary relevance.

Where the outcome of the articles is that the outcomes have 'implications for policy' $(n=41), 66 \%$ do not analyse the policies concerned. Again, these articles seem to see policies as something that the authors want to have an impact on but in a very general way without getting into the details of particular policies.

Of those articles where the outcomes is a critique of policy $(n=13)$, over half do not analyse the policies and $15 \%$ do not explain the approach to policy analysis. The remaining $31 \%$ of articles take a general critique meaning that none have a named approach to analysis. Over half of these articles just use the policy to set the context of the article. 


\begin{tabular}{|c|c|c|c|c|c|c|c|}
\hline & & $\begin{array}{c}\text { Not } \\
\text { discussed }\end{array}$ & $\begin{array}{c}\text { Provides } \\
\text { context }\end{array}$ & $\begin{array}{l}\text { Object of } \\
\text { analysis }\end{array}$ & $\begin{array}{l}\text { Policy as } \\
\text { evidence }\end{array}$ & $\begin{array}{c}\text { Object of } \\
\text { development }\end{array}$ & Total \\
\hline \multirow[t]{5}{*}{ No Outcome } & Not analysed & $5(25 \%)$ & $12(60 \%)$ & $1(5 \%)$ & $1(5 \%)$ & 0 & $19(95 \%)$ \\
\hline & Not stated & 0 & 0 & 0 & 0 & 0 & 0 \\
\hline & $\begin{array}{l}\text { General textual } \\
\text { analysis }\end{array}$ & 0 & $1(5 \%)$ & 0 & 0 & 0 & $1(5 \%)$ \\
\hline & $\begin{array}{l}\text { Named approach } \\
\text { to analysis }\end{array}$ & 0 & 0 & 0 & 0 & 0 & 0 \\
\hline & Total & 5 & 13 & 1 & 1 & 0 & $\begin{array}{r}20 \\
(100 \%) \\
\end{array}$ \\
\hline \multirow{5}{*}{$\begin{array}{l}\text { Implications for } \\
\text { policies }\end{array}$} & Not analysed & $2(5 \%)$ & $9(22 \%)$ & $10(24 \%)$ & $3(7 \%)$ & $3(7 \%)$ & $27(66 \%)$ \\
\hline & Not stated & 0 & $2(5 \%)$ & $1(2 \%)$ & $3(7 \%)$ & 0 & $6(15 \%)$ \\
\hline & $\begin{array}{l}\text { General textual } \\
\text { analysis }\end{array}$ & 0 & $1(2 \%)$ & $1(2 \%)$ & 0 & 0 & $2(5 \%)$ \\
\hline & $\begin{array}{l}\text { Named approach } \\
\text { to analysis }\end{array}$ & 0 & 0 & $3(7 \%)$ & $3(7 \%)$ & 0 & $6(15 \%)$ \\
\hline & Total & 2 & 12 & 15 & 9 & 3 & $\begin{array}{r}41 \\
(100 \%) \\
\end{array}$ \\
\hline \multirow{5}{*}{$\begin{array}{l}\text { Critiques of } \\
\text { policies }\end{array}$} & Not analysed & $1(8 \%)$ & $5(39 \%)$ & $1(8 \%)$ & 0 & 0 & $7(54 \%)$ \\
\hline & Not stated & 0 & $2(15 \%)$ & 0 & 0 & & $2(15 \%)$ \\
\hline & $\begin{array}{l}\text { General textual } \\
\text { analysis }\end{array}$ & 0 & 0 & $1(8 \%)$ & $3(23 \%)$ & & $4(31 \%)$ \\
\hline & $\begin{array}{l}\text { Named approach } \\
\text { to analysis }\end{array}$ & 0 & 0 & 0 & 0 & 0 & 0 \\
\hline & Total & 1 & 7 & 2 & 3 & & $\begin{array}{r}13 \\
(100 \%) \\
\end{array}$ \\
\hline \multirow{5}{*}{$\begin{array}{l}\text { Charts policy } \\
\text { development }\end{array}$} & Not analysed & 0 & $1(4 \%)$ & 0 & $4(16 \%)$ & 0 & $5(20 \%)$ \\
\hline & Not stated & 0 & $4(16 \%)$ & 0 & $6(24 \%)$ & 0 & $10(40 \%)$ \\
\hline & $\begin{array}{l}\text { General textual } \\
\text { analysis }\end{array}$ & 0 & $1(4 \%)$ & $2(8 \%)$ & $4(16 \%)$ & & $7(28 \%)$ \\
\hline & $\begin{array}{l}\text { Named approach } \\
\text { to analysis }\end{array}$ & 0 & 0 & $2(8 \%)$ & $1(4 \%)$ & 0 & $3(12 \%)$ \\
\hline & Total & 0 & 6 & 4 & 15 & 0 & $\begin{array}{r}25 \\
(100 \%) \\
\end{array}$ \\
\hline Total & & 8 & 38 & 22 & 28 & 3 & 99 \\
\hline
\end{tabular}

Table 5: Relations between policy outcomes, analysis and use of policy texts

Finally, where the outcome is to chart the development of policies $(n=25), 20 \%$ of articles do not analyse policy texts and $40 \%$ do not state the ways in which policies have been analysed. This seems 
In press in Higher Education. Available at:

http://link.springer.com/article/10.1007/s10734-014-9819-9

to reflect a tendency in policy history studies not to explain the ways in which policy texts have been analysed, with only $12 \%$ of articles having a named approach to policy analysis.

\section{Discussion}

If we come back to the central question of this article, how are policy texts positioned in higher education research? Unsurprisingly they seem to be positioned in different ways in different articles; however there are some discernible trends in the sample of articles that we examined in relation to the use and analysis of the policy texts concerned.

In relation to the use of policy texts, these trends seem to reflect the criticisms outlined earlier by educational researchers because the policy texts that are generally used in national rather than relational terms and are more focused on the impact of policies rather than explicitly critiquing them (Ball 1994; Ozga 2000; Vidovich 2007; Simons, Olssen, \& Peters 2009; Saarinen and Ursin 2012; Taylor Webb 2014). In common with Saarinen (2008), we generally found very few articles that gave an explicit account of how they had analysed policy texts.

However, our analysis suggests that there is a much bigger problem in the analysis of policy texts, which reflects the criticisms made by policy makers (Whitty 2006). This is the lack of sustained analysis of specific policies, their origins, and their outcomes. Instead, many articles seem to be based on a very general notion of policy, in which the role of specific policies is difficult to discern. This means that, as a whole, the articles in our sample were more focused on having an impact on policies rather than studying them. Over a quarter of the articles did not name any policies, nearly $60 \%$ did not analyse policies but $80 \%$ of the articles claimed to have outcomes for policies. Four further examples give a stark sense of this problem. First $66 \%$ of those articles that claim to show the impact 
In press in Higher Education. Available at:

http://link.springer.com/article/10.1007/s10734-014-9819-9

of policies, do not contain any analysis of policy texts. This makes it very difficult for a reader to assess the claims made because the way in which the policy text led to this impact is not explored.

Second, $54 \%$ of critiques of policies do not contain an analysis of specific policy texts and none outlined a specific approach to analysing policy texts. This means that they tend not to be specific about the policies that are being critiqued and that they do not explain the ways in which they have subjected them to critical analysis. Paradoxically, this suggests that there is an uncritical engagement with policy texts by those who critique policies, which is in some ways in reminiscent of the criticisms made of uncritical researchers by those who take a critical stance (Ball 1994; Ozga 2000; Vidovich 2007; Simons, Olssen, \& Peters 2009; Taylor Webb 2014).

Third, in none of the cases where the policy was an object of development did the articles actually analyse policy texts. It is difficult to understand how a policy can be effectively developed if the researchers have not engaged in an in-depth analysis of the existing policy texts because it is unclear how the proposed development is situated in relation to the existing policy.

Fourth, in our analysis only 7 out of 99 articles focused on a specific policy, with an explicit way of analysing that policy text, used the policy to do more than simply provide context for the research and had a clear outcome in relation to the policy. This means that sustained analyses of the relations between particular policy texts and higher education practices is very much the exception in higher education research. This is not to suggest that all articles need to do this but it does seem remarkable that such a small proportion of articles should involve a sustained analysis of both the content and impact of particular policies. 
In press in Higher Education. Available at:

http://link.springer.com/article/10.1007/s10734-014-9819-9

These problems suggest that whilst policy makers may be fond of policy-informed evidence

(Hartley2005), the sample of journal articles that we analysed give the appearance that researchers are equally keen on research-created-policies: policies that they create through their analysis of data rather than through an analysis of policy documents. It is important to be clear that we deliberately use the word 'appearance'. This is because our analysis is simply based on the ways in which research into higher education policy is reported in a selection of journals in a particular year. Thus it is perfectly possible that the research in these articles is based on an in-depth analysis of policy texts but that this is not something that is included in the material selected for the article. However, even if this is the case, it still means that these analyses are not subjected to the peer review process and are situated at the level of individual researchers or groups of researchers rather than made public through publication in journal articles.

Overall, this leaves us with very little knowledge about the ways in which individual policies impact on practices in higher education, how they are resisted, adapted or ignored in particular contexts. Thus from this perspective it is easy to understand policy makers frustrations with educational research.

\section{Conclusion}

Within the current higher education research arena, there are calls, both nationally and internationally, for research to be relevant to policy. This may account for the number of articles in journals (both policy focussed and more general) that describe themselves as policy articles. Given this, how policy is situated within higher education becomes an important consideration. Our analysis has shown that the use of policy texts in higher education research appears to be vague, unfocussed, and uncritically accepted as an accurate depiction of reality. Such research is unlikely to have an impact on policy nor will it contribute to the development of convincing critiques of policy. We 
In press in Higher Education. Available at:

http://link.springer.com/article/10.1007/s10734-014-9819-9

therefore call, as a result of the analysis presented here, for more sustained, in-depth, analytical and critical research into the development and impact of higher education policies that clearly examines the relations between policy texts and practices within higher education.

\section{References}

Ashwin, P (2012). How often are theories developed through empirical research in higher education? Studies in Higher Education, 37: 941-955

Bacchi, C. (2000). Policy as discourse: what does it mean? Where does it get us? Discourse 21: 45-57.

Ball, S. (1994). Education reform: a critical and post-structuralist approach. Buckingham: Open University Press.

Chalmers, I. (2005). If evidence-informed policy works in practice, does it matter if it doesn't work in theory? Evidence \& Policy, 1: 227-242.

Hammersley, M. (2005). Is the evidence-based practice movement doing more good than harm? Reflections on lain Chalmers' case for research-based policymaking and practice Evidence \& Policy, 1: 85-100.

Hardy, I. (2009). The politics of educational policy studies: a preliminary analysis of leading educational policy journal articles. Critical Studies in Education, 50: 173-185.

Hartley, D. (2006). Pulling us apart? Relativism and instrumentalism in contemporary educational research, Educational Review, 58:3, 269-272,

Law, J. (1994). Organizing Modernity. Oxford: Blackwell.

Lingard, B. and Sellar, S. (2013). Globalization, edu-business and network governance: the policy sociology of Stephen J. Ball and rethinking education policy analysis. London Review of Education, $11: 3,265-280$.

Nudzor, H. (2009). Reconceptualising the paradox in policy implementation: a post-modernist conceptual approach. Discourse, 30: 501-513. 
In press in Higher Education. Available at:

http://link.springer.com/article/10.1007/s10734-014-9819-9

Ozga, J. 2000. Policy research in educational settings: contested terrain. Buckingham: Open University Press.

Simons, M., Olssen, M., \& Peters, M. (2009). Re-reading education policies: Part I and Part II. In Simons, M., Olssen, M., \& Peters, M (eds.) Re-reading education policies: a handbook studying the policy agenda of the $21^{\text {st }}$ Century (1-95). Rotterdam: Sense Publishers.

Saarinen, T. (2008). Position of text and discourse analysis in higher education policy research. Studies in Higher Education, 33: 719-728.

Saarinen, T. and Ursin, J. (2012). Dominant and emerging approaches in the study of higher education policy change. Studies in Higher Education, 37: 143-156.

Saunders, L. (2005). Research and policy: reflections on their relationship Evidence \& Policy, 1: 383390.

Smith, K. (2010). Research, policy and funding: academic treadmills and the squeeze on intellectual spaces. British Journal of Sociology, 61: 176-195.

Taylor, S. (1997) Critical policy analysis: exploring contexts, texts and consequences, Discourse: Studies in the Cultural Politics of Education, 18, 23-35.

Taylor, S. (2004) Researching educational policy and change in 'new times': using critical discourse analysis, Journal of Education Policy, 433-451

Taylor Webb, P. (2014). Policy problematization, International Journal of Qualitative Studies in Education, 27, 364-376.

Tight, M. (2012). Researching higher education. Second Edition. Maidenhead: McGraw-Hill International.

Tight M. (2007). Bridging the Divide: A comparative analysis of articles in higher education journals published inside and outside North America. Higher Education 53: 235-253. 
In press in Higher Education. Available at:

http://link.springer.com/article/10.1007/s10734-014-9819-9

Vidovich, L. (2007) Removing policy from its pedestal: some theoretical framings and practical possibilities, Educational Review, 59(3), 285-298

Weaver-Hightower, M. (2008). An ecology metaphor for educational policy analysis: a call for complexity, Educational Researcher, 37(3), 153-167

Whitty, G. (2006). Education(al) research and education policymaking: is conflict inevitable? British Educational Research Journal, 32:2, 159-176, 